\title{
Systematic status of Manaosia bracodemoca Woodland, 1935 and Paramonticellia itaipuensis Pavanelli et Rego, 1991 (Eucestoda: Proteocephalidea), parasites of Sorubim lima (Siluriformes: Pimelodidae) from South America
}

\author{
Alain de Chambrier \\ Muséum d'Histoire Naturelle, P.O. Box 6434, CH-1211 Geneva 6, Switzerland
}

Key words: Proteocephalidea, Manaosia bracodemoca, Paramonticellia itaipuensis, Sorubim lima, Brazil, Paraguay

\begin{abstract}
Type material of the proteocephalidean cestodes Manaosia bracodemoca Woodland, 1935 and Paramonticellia itaipuensis Pavanelli et Rego, 1991 (both monotypic genera) as well as recently collected material of the latter species are redescribed. A close similarity between both species was observed: the shape of scoleces is identical, both possess a globular scolex with hidden suckers, a well-developed circular, horseshoe-shaped musculature surrounding suckers; the measurements of both taxa are also similar (scolex, suckers, young proglottides). Both cestodes possess a medullary ovary crossing the dorsal muscle layer and ending in the dorsal cortex, the testes are in the dorsal cortex and the cortical vitellarium is laterally situated. Both species parasitize the same fish host. Therefore Paramonticellia is considered a junior synonym of Manaosia and Paramonticellia itaipuensis becomes a junior synonym of Manaosia bracodemoca. An emended diagnosis of Manaosia, which is a monotypic genus, is provided.
\end{abstract}

In 1991, Pavanelli and Rego described two new genera and three new species: Paramonticellia itaipuensis, Goezeella nupeliensis and Nupelia portoricensis, and another species Spatulifer cf. maringaensis Pavanelli et Rego, 1989, in the siluriform fish Sorubim lima (Schneider) from the Parana River basin (Pavanelli and Rego 1989, 1991). De Chambrier and Vaucher (1999) synonymised Goezeella nupeliensis with Paramonticellia itaipuensis. New material of all these species was obtained from the same host during field expeditions in both the Parana and Amazonian basins. During studies of Woodland's type material deposited in the Natural History Museum in London, a similarity was noticed between the monotypic genera Paramonticellia Pavanelli et Rego, 1991 and Manaosia Woodland, 1935, the latter being considered as genus inquirendum (Freze 1965, Rego 1994, Rego et al. 1999). The aim of this study was to revise the type material of both genera and compare it with recently collected specimens in order to clarify their generic and specific status.

\section{MATERIALS AND METHODS}

Immediately after dissection of fish, the recently collected worms were fixed with a hot $4 \% \mathrm{v} / \mathrm{v}$ neutral formaldehyde solution, then stained with Mayer's hydrochloric carmine solution, dehydrated in an ethanol series, cleared with Eugenol (clove oil), and mounted in Canada balsam. Pieces of strobila were embedded in paraffin wax, cross sectioned (thickness $12-15 \mu \mathrm{m})$, stained with Weigert's haematoxylin and counterstained with $1 \%$ eosin $\mathrm{B}$ according to the methods recently published by de Chambrier (2001). All measurements are given in micrometres.

Abbreviations used in descriptions: $\mathrm{x}=$ mean, $\mathrm{n}=$ number of measurements, $\mathrm{CV}=$ coefficient of variability $(\%), \mathrm{OV}=$ ovary width to proglottis width ratio, $\mathrm{PG}=$ position of the genital pore to proglottis length ratio (\%), PC = cirrus pouch length to proglottis width ratio $(\%), \mathrm{MT}=$ type material. Material is deposited at the Natural History Museum (MHNG), Geneva, Switzerland.

Material examined

Syntype material of Manaosia bracodemoca Woodland, 1935 from the Natural History Museum, London: BMNH 1965.2.24.106-108, field number Amaz 8, 1 whole mount preparation, 1 slide of frontal scolex sections, 7 slides of transversal scolex sections. The whole mount preparation bears 5 pieces of Manaosia and probably one piece of Spatulifer cf. maringaensis.

Type material of Paramonticellia itaipuensis Pavanelli et Rego, 1991 from the helminthological collection of the Instituto Oswaldo Cruz, Rio de Janeiro: holotype IOC 32.560a, paratypes IOC $32.560 \mathrm{~b}-\mathrm{c}$, IOC $32.561 \mathrm{a}-\mathrm{b}$, Rio Paraná, Itaipu and Porto Rico, Paraná, Brasil. Goezeella nupeliensis Pavanelli et Rego, 1991: holotype IOC 32.562a, paratypes IOC 32.562b-c, IOC 32.563a, Rio Paraná, Itaipu and Porto Rico, Paraná, Brasil $(=P$. itaipuensis; see de Chambrier and Vaucher 1999).

Recently collected material (deposited in MHNG): Rio Paraná, Campichuelo, Province Itapua, 28.02.1987, 17909 INVE; Rio Paraguay, San Antonio, Central Province, 28.10.1989, 17908 INVE, 27.11.1993, 19354 INVE, 04.11.1995, 21855 INVE; Itacoatiara, Rio Amazonas, Brasil, 03.10.1995, 32813 INVE. 



Figs. 1, 2, 4. Paramonticellia itaipuensis Pavanelli et Rego, 1991. Fig. 1. Scolex, ventral view, 32813 INVE. Fig. 2. Cross section of the scolex at level of one sucker, 17908 INVE. Fig. 4. Cross section of the scolex, 17908 INVE. Fig. 3. Manaosia bracodemoca Woodland, 1935. Cross section of the scolex, syntype BMNH 1965.2.24.106-108. All figures: note the shape of the circular musculature. Scale bars: Figs. $1-4=500 \mu \mathrm{m}$. 


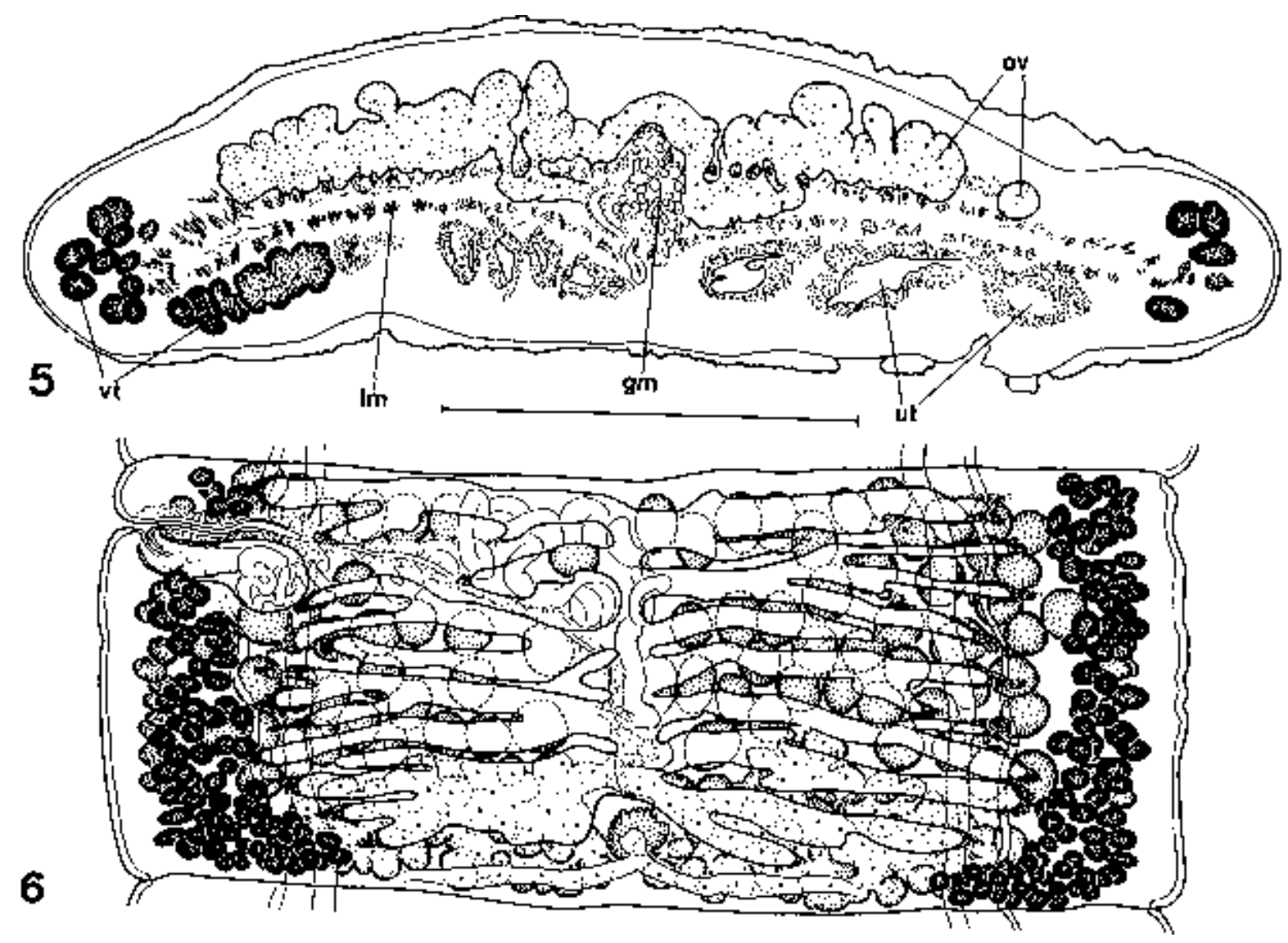

Figs. 5, 6. Paramonticellia itaipuensis Pavanelli et Rego, 1991. Fig. 5. Paratype IOC 32.561 b, cross section at level of the ovary (from de Chambrier and Vaucher 1999). Fig. 6. Pregravid proglottis, ventral view, 17908 INVE (from de Chambrier and Vaucher 1999). Abbreviations: gm - Mehlis' glands; lm - longitudinal internal musculature; ov - ovary; ut - uterus; vt - vitelline follicles. Scale bar: Figs. 5, $6=500 \mu \mathrm{m}$.

\section{RESULTS}

Redescription of Manaosia bracodemoca Woodland, 1935

Figs. 3, 8

Type host according to Woodland: Platystoma sp.; supposed type host: Sorubim lima, vernacular name "Braço-de-Moça"

Description (type material): In the whole mounted syntype material, six fragments of immature strobila were observed. The finest and longest piece did not fit with the others and could belong to Spatulifer cf. maringaensis Pavanelli et Rego, 1989. The remaining fragments are very contracted and no scolex is present. As stated by Woodland $(1935$, p. 213), it is almost impossible to observe the morphology in these whole mounted pieces. He gave some measurements: "Strobila 6-7 mm long and 700 wide, scolex globular, with a wrinkled surface, 940 in diameter, suckers, 330 in diameter, entirely hidden in scolex, neck 320 wide. The testes are cortical, the ovary consists of lobules situated in the medulla, which produce dorsal expansion ending in the dorsal cortex. No trace of uterus was to be seen and vitellaria were not identified." Examination of type specimen made it possible to describe more characters.

Even though most cross sections are damaged (loss of the tegument, subtegument and a part of the peripheral parenchyma), some of them can be observed, notably at the scolex level. The globular shape of the scolex (835 in diameter) with deeply hidden suckers was observed (Fig. 3). The suckers bear a hypertrophied circular musculature acting as sphincter (Fig. 3). Cross sections of proglottides show medullary-cortical position of the ovary, cortical position of the testes and vitellaria and a developed internal longitudinal musculature (Fig. 8).

Paramonticellia Pavanelli et Rego, 1991

Paramonticellia itaipuensis Pavanelli et Rego, 1991

Figs. 1, 2, 4-7, 9-12

(Syn. Goezeella nupeliensis Pavanelli et Rego, 1991)

H o s t : Sorubim lima (Schneider, 1801).

Preva 1 e n c e $=25 \% ; \mathrm{n}=24$; intensity $=1-15$; abundance $=1.25$. 

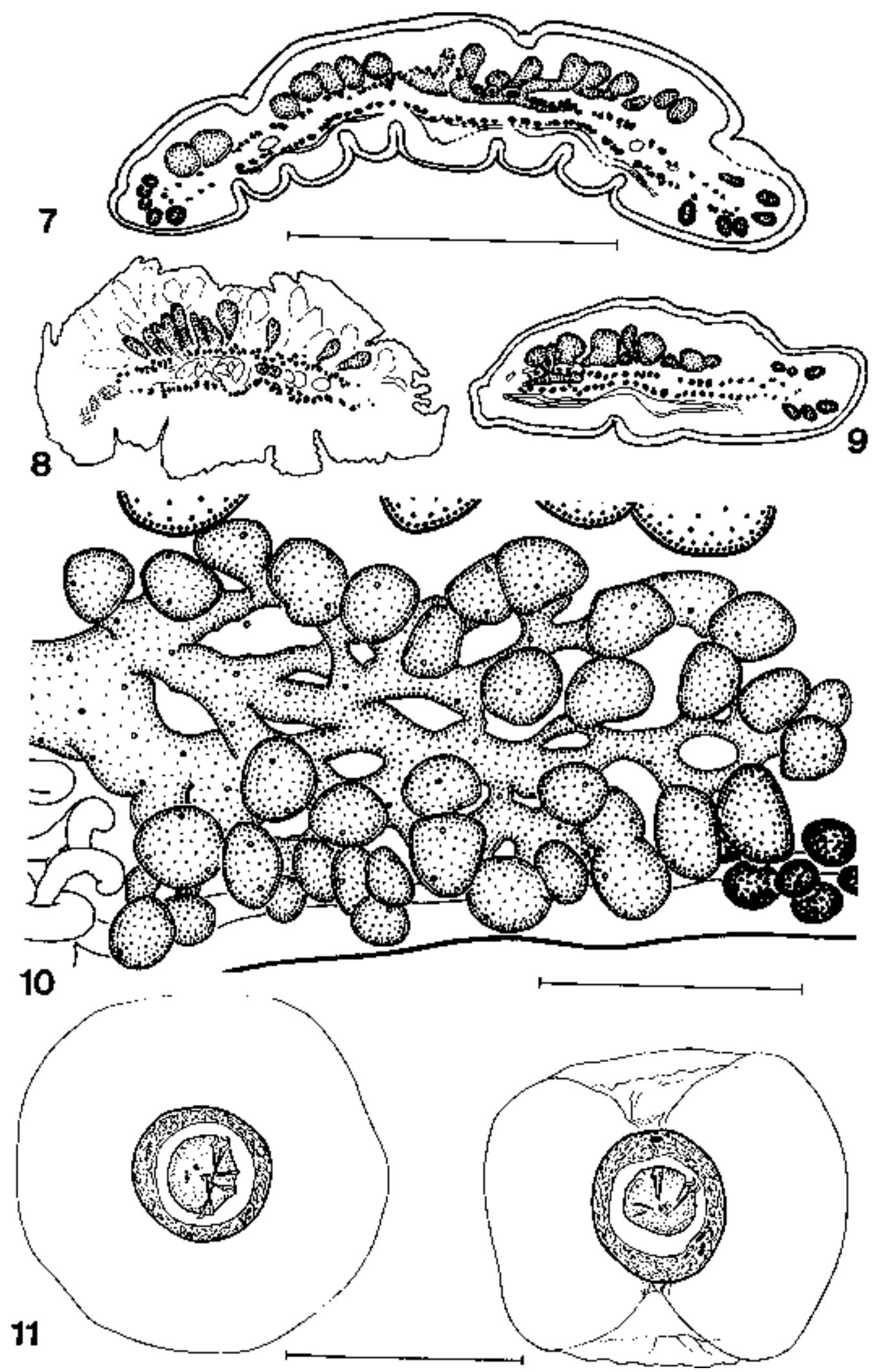

Figs. 7, 9-11. Paramonticellia itaipuensis Pavanelli et Rego, 1991. Fig. 7. Cross section at posterior level of proglottis, 19354 INVE. Fig. 8. Manaosia bracodemoca Woodland, 1935. Cross section at level of the ovary, syntype BMNH 1965.2.24.106-108. Fig. 9. Cross section at level of the ovary, 19354 INVE. Fig. 10. Detail of the lateral lobe of the ovary with dorsal outgrowths, 17908 INVE. Fig. 11. Eggs drawn in distilled water, 19354 INVE. Scale bars: Figs. $7-9=500 \mu \mathrm{m}$; Fig. $10=125 \mu \mathrm{m}$; Fig. $11=$ $50 \mu \mathrm{m}$. 

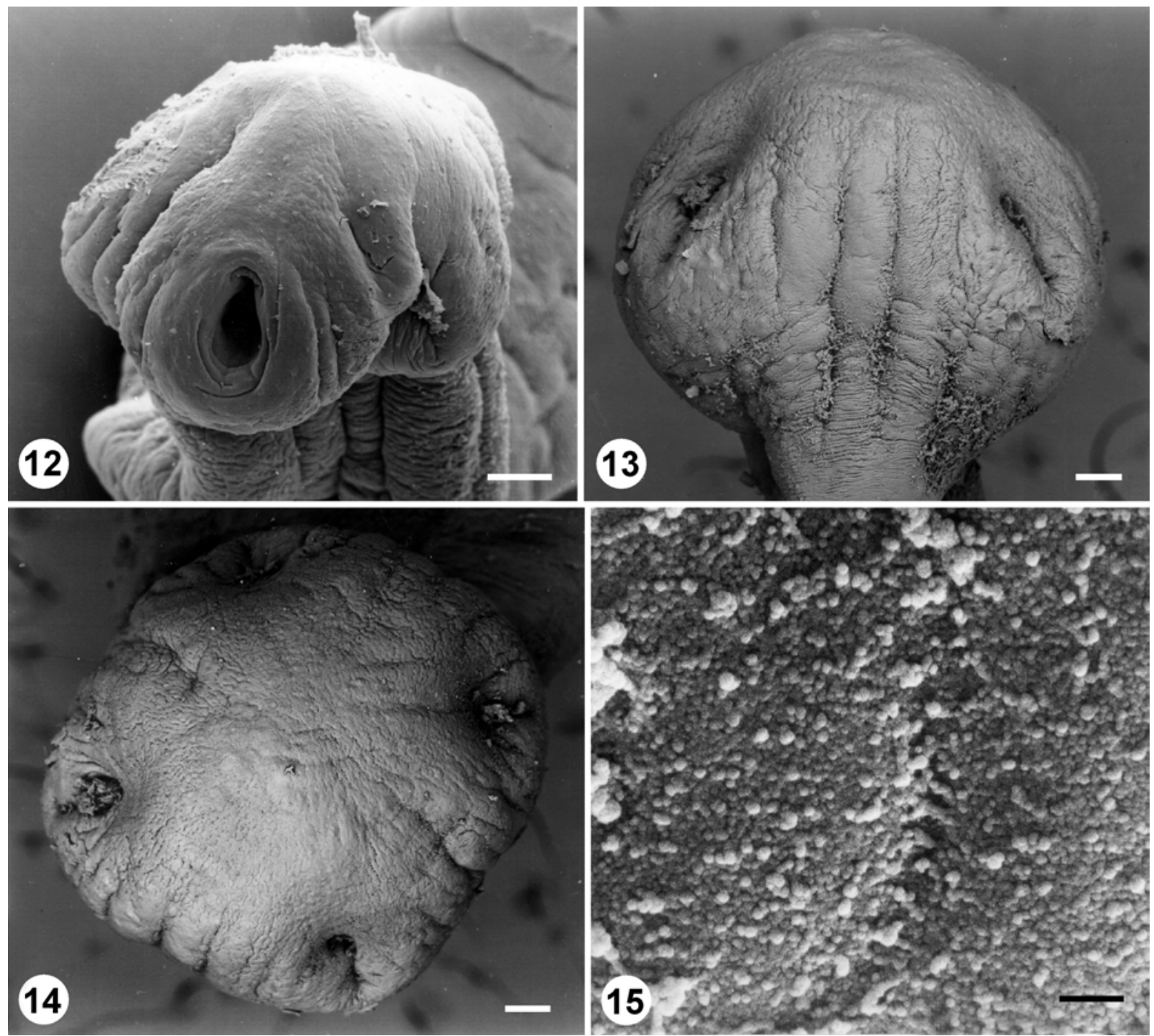

Figs. 12-15. Paramonticellia itaipuensis Pavanelli et Rego, 1991. Scanning electron micrographs of the scolex. Fig. 12. Anterolateral view showing an opened sucker. Fig. 13. Lateral view. Fig. 14. Apical view. Fig. 15. Detail of the apex showing the shape of microtriches. Scale bars: Figs. $12-14=100 \mu \mathrm{m}$; Fig. $15=2 \mu \mathrm{m}$.

Description (based on recently collected material and type material): Proteocephalidea, Monticelliidae, Monticelliinae. Testes, ovary, uterus, vitelline follicles in cortex.

Strobila 15-20 mm long, with about 65 proglottides. Scolex globular (Figs. 12-14), possessing abundant internal musculature and a dense network of osmoregulatory canals (Figs. 1, 4). Internal suckers with a circular, horseshoe-shaped musculature situated in its marginal part and acting as a sphincter, closing the cavity of sucker (Figs. 1, 2, 4). Round to oblong cells of finely granular cytoplasm, elongated in direction of the scolex surface, beneath the apex of the scolex present (Fig. 1). Scolex 910-1105 (MT = 1320, somewhat flat) in diameter (Figs. 1, 12-14), suckers 360-460 (MT = $385-445)$ in diameter. Scolex covered by small dense microtriches (Fig. 15). Longitudinal internal musculature dense, formed by bundles of fibres with few anastomoses (Figs. 5, 7, 9). Bundles of fibres parallel to posterior edge of proglottides and posteriorly to the ovary. Ventral osmoregulatory canals crossing base of cirrus pouch; dorsal osmoregulatory canals in contact with vitelline follicles (Figs. 6, 7).

Testes $55-100$ in number $(\mathrm{x}=77, \mathrm{n}=35, \mathrm{CV}=17 \%)$ (MT $=76-90, x=82), 5-14$ preporal, 17-38 postporal and 23-53 aporal, in one dorsal field, in one layer dorsally overlapping cirrus pouch and vas deferens, reaching laterally to vitelline follicles (Fig. 6), 50-80 in diameter.

Genital pores irregularly alternating, opening between 15 and $23 \%(\mathrm{n}=31, \mathrm{CV}=12 \%)$ of proglottis length. Genital atrium present. Cirrus pouch pyriform, 
165-250 long. $\mathrm{PC}=14-21 \%(\mathrm{x}=17 \%, \mathrm{n}=26, \mathrm{CV}=$ $12 \%$, MT $=14-16 \%)$. Cirrus occupying $55-70 \%$ of cirrus pouch length. Vagina always anterior to cirrus pouch, without observable vaginal sphincter.

Ovary bilobate, cortical, dorsal, with numerous dorsal outgrowths (Figs. 5, 7), deeply folliculate in gravid proglottides (Fig. 10). Isthmus of ovary medullary (Figs. 5, 7). $\mathrm{OV}=60-72 \%(\mathrm{x}=66 \%, \mathrm{n}=32, \mathrm{CV}=$ $5 \%$, MT $=66-74 \%)$. Vitelline follicles cortical, in two lateral bands, crescent-shaped in cross sections. Portion of posterior ventral vitelline follicles confluent, passing distal part of ovary (Figs. 5, 6).

Primordium of uterine stem cortical, already present in immature proglottides. Formation of uterus: in immature proglottides, chromophil cells concentrated laterally on both sides of uterine stem; in first mature proglottides, lateral ramified digitations with a lumen, occupying at this stage already about $65 \%$ of proglottis width; in gravid proglottides, lateral diverticles occupying up to $90 \%$ of gravid proglottis width. Uterus with 5$8(\mathrm{MT}=7-10)$ lateral diverticles on each side (Fig. 6) and one or several ventral longitudinal precocious apertures.

Eggs spherical, with hyaline outer envelope about 80 in diameter; embryophore round to ovoid, consisting of two layers; outer layer larger than nuclei-containing envelope, 25-30 in diameter; oncospheres spherical, 11-13 in diameter with 6 hooklets 8-10 long (Fig. 11). Last proglottides still containing some eggs. Early appearance of hooklets in oncospheres. Some proglottides with hyperparasitic proteocephalidean cestodes and undetermined nematode larvae.

H o s t : Sorubim lima (Schneider, 1801)

Remarks: The paratype of $P$. itaipuensis No. IOC $32560 \mathrm{~b}$ is in good condition. The paratype No. IOC $32560 \mathrm{c}$, even though of poor quality, fits with recently collected specimens. It is characterised by a similar number of testes $(55-100$, MT $=76-90)$, by the presence of a horseshoe-shaped developed circular musculature of suckers (Figs. 1, 2, 4), by confluent ventral vitelline follicles overlapping the distal part of the ovary (Fig. 6), by a particular development of the uterus with digitate and ramified diverticles (Fig. 6), and by the presence of early embryonated eggs in the uterus (Fig. 11).

Pavanelli and Rego (1991) observed portions of the cortical ovary projecting outgrowths in the medulla. On the contrary, de Chambrier and Vaucher (1999, p. 202203) observed that only a part of the ovary isthmus is medullary, before penetrating into the dorsal cortex, across the internal longitudinal musculature (Fig. 5).

\section{DISCUSSION}

In Manaus, Woodland (1935) found a new cestode which he named Manaosia bracodemoca in reference to the local name of the host, "Braço-de-Moça". This host was tentatively identified as "Platystoma sp." according to Dr. J.R. Norman (Woodland 1935, p. 213). It is probable that this fish was in fact conspecific with Sorubim lima, whose vernacular name is "Braço-deMoça" in Central Amazonia (Mendes Dos Santos et al. 1984). According to these authors, this name can also be applied to Platystomatichthys sturio. Contrary to the opinion of Mendes Dos Santos et al. (1984), the Platystomatichthys sturio was named "Karuatayi" by local fishermen in Manaus and in Itacoatiara markets. "Braço-de-Moça" was used only for Sorubim lima, as confirmed by local fishermen during my stays in Central Amazonia in 1992 and 1995.

When comparing the scoleces of Manaosia bracodemoca and Paramonticellia itaipuensis, a close similarity can be observed: the shape of scoleces is identical, in both species being globular with interiorly hidden suckers, and with a circular horseshoe-shaped musculature surrounding the suckers. Furthermore, the size of young proglottides of both species is similar in cross sections, both possessing a medullary ovary with outgrowths crossing dorsally and ending in the dorsal cortex, testes in the dorsal cortex and cortical vitellaria situated laterally. In the type material of Manaosia, the uterus was not observable, probably because of immature condition of fragments. The only difference noted was in the shape of the internal longitudinal musculature, which is more developed medially than laterally in Manaosia. However, this particularity may be explained by the very poor state of preservation of the original material, which lost its tegumental and subtegumental layers (Woodland 1935, p. 213). Given the close morphological similarity between Manaosia and Paramonticellia and their presence in the same host, we conclude that both genera are synonyms.

Consequently, the more recent genus Paramonticellia becomes a junior synonym of Manaosia and Paramonticellia itaipuensis becomes a junior synonym of Manaosia bracodemoca. An updated diagnosis of Manaosia is given below.

\section{Manaosia Woodland, 1935 \\ Syn. Paramonticellia Pavanelli et Rego, 1991}

Diagnosis: Proteocephalidea, Monticelliidae, Monticelliinae. Worms of small size; scolex globular; suckers uniloculate, deeply embedded in scolex, with developed circular musculature in their distal margin; apical glandular cells situated between suckers and apical tegument; internal longitudinal musculature developed; testes cortical, in one layer; vagina anterior to cirrus pouch; genital pore anterior, irregularly alternating; ovary bilobate, cortical, dorsal, with numerous dorsal strongly lobulate outgrowths; ovarian isthmus medullary; vitelline follicles cortical, in two lateral bands, crescent-shaped in cross sections, with tendency of posterior concentration; uterine primordium and lateral branches cortical; parasites of pimelodid catfishes. Type species: Manaosia bracodemoca Woodland, 1935. 
Acknowledgements. I am indebted to Dely Noronha de B. Pinto (Rio de Janeiro), to David I. Gibson and Eileen Harris (London) for loan of the type material. I am grateful to Amilcar Arandas Rego (Rio de Janeiro) and Carlo Dlouhy
(Asunción) for collaboration in collecting material in the field, to Jean Mariaux (Genève), who provided useful comments on earlier versions of the manuscript, and to Gilles Roth (Genève) for his help with drawings.

\section{REFERENCES}

de CHAMBRIER A. 2001: A new tapeworm from the Amazon, Amazotaenia yvettae gen. n., sp. n., (Eucestoda: Proteocephalidea) from the siluriform fishes Brachyplatystoma filamentosum and B. vaillanti (Pimelodidae). Rev. Suisse Zool. 108: 303-316.

de CHAMBRIER A., VAUCHER C. 1999: Proteocephalidae et Monticelliidae (Eucestoda: Proteocephalidea) parasites de poissons d'eau douce au Paraguay, avec descriptions d'un genre nouveau et de dix espèces nouvelles. Rev. Suisse Zool. 106: 165-240.

FREZE V.I. 1965: [Proteocephalids - Tapeworm Helminths of Fish, Amphibians and Reptiles. Essentials of Cestodology. Vol. V.] Publishing House Nauka, Moscow, 540 pp. (In Russian.)

MENDES Dos SANTOS G., JEGU M., de MERONA B. 1984: Catalogo de peixes comerciais do baixo Rio Tocantins; Projeto Tucurui. Eds Electronorte/ CNPq/ INPA, Manaus, 83 pp.
PAVANELLI G.C., REGO A.A. 1989: Novas especies de proteocefalídeos (Cestoda) de Hemisorubim platyrhynchos (Pisces - Pimelodidae) do estado do Paraná. Rev. Bras. Biol. 49: 381-386.

PAVANELLI G.C., REGO A.A. 1991: Cestóides proteocefalídeos de Sorubim lima (Schneider, 1801) (Pisces Pimelodidae) do Rio Paraná e reservatorio de Itaipu. Rev. Bras. Biol. 51: 7-12.

REGO A.A. 1994: Order Proteocephalidea. In: L.F. Khalil, A. Jones and R.A. Bray (Eds.), Keys to the Cestode Parasites of Vertebrates. Commonwealth Agricultural Bureaux, Wallingford, UK, pp. 257-293.

REGO A.A., CHUBB J.C., PAVANELLI G.C. 1999: Cestodes in South American freshwater teleost fishes: keys to genera and brief descriptions of species. Rev. Bras. Biol. 16: 299-367.

WOODLAND W.N.F. 1935: Some more remarkable cestodes from Amazon siluroid fish. Parasitology 27: 207-225.

Accepted 11 September 2002 